\title{
Expression variations of two retinoid signaling pathway receptors in the rotifer Brachionus calyciflorus exposed to three endocrine disruptors
}

\author{
C. Joaquim-Justo ${ }^{1} \cdot$ E. Gismondi ${ }^{1}{ }^{1}$
}

Accepted: 24 December 2020

(c) The Author(s), under exclusive licence to Springer Science+Business Media, LLC part of Springer Nature 2021

\begin{abstract}
Endocrine disruption compounds (EDC) are known to affect reproduction, development, and growth of exposed organisms. Although in vertebrates, EDCs mainly act through steroid receptors (e.g. androgen and estrogen receptors), their absence in many invertebrates suggests the involvement of another biological pathway in endocrine disruption effects. As retinoid signaling pathway is present in almost all Metazoa and its involvement in the endocrine disruption of gastropods (i.e. imposex) has been demonstrated, the present work was devoted to investigating the relative mRNA variations of two retinoid receptors genes, retinoid $\mathrm{X}$ receptor (RXR) and retinoid acid receptor (RAR), in the freshwater rotifer Brachionus calyciflorus exposed for 6,12 and $24 \mathrm{~h}$ to flutamide, fenitrothion and cyproterone acetate, three anti-androgens known to disrupt sexual reproduction of Brachionus sp. Results revealed that fenitrothion did not affect the relative mRNA levels RXR and RAR in B. calyciflorus, whereas RXR and RAR mRNA levels could be significantly increased by 2 to 4.5 -fold and from 2 to 7 -fold after exposure to flutamide and cyproterone acetate, respectively. Moreover, the effects of flutamide and cyproterone acetate were measured from 6 and $12 \mathrm{~h}$ of exposure, respectively. Cyproterone acetate caused the highest increase of RXR and RAR mRNA levels, probably due to its progestin activity in addition to its anti-androgenic activity and the potential presence of a membrane-associated progesterone receptor as reported in Brachionus manjavacas. Consequently, although it is still difficult to evaluate the hormonal pathways involved in the endocrine disruption in Brachionus sp., this work suggests that the retinoid signaling pathway appears to be a good starting point to try to elucidate the molecular mechanisms involved in sexual reproductive dysfunction in Brachionidae.
\end{abstract}

Keywords Retinoid X receptor $\cdot$ Retinoid acid receptors $\cdot$ Anti-androgens $\cdot$ Endocrine disruption $\cdot$ Brachionus $\mathrm{sp}$

\section{Introduction}

Endocrine Disrupting Compounds (EDCs) have become a major concern in ecology becausee of their ability to interfere with mechanisms related to the endocrine system of exposed organisms, and thus disrupt biological processes such as reproduction, development and growth (Matthiessen 2003; World Health Organization (WHO) 2002). In the beginning, many studies carried out in vertebrates showed that EDCs act through estrogen and/or androgen receptors,

\footnotetext{
E. Gismondi

eric.gismondi@uliege.be

1 Laboratory of Animal Ecology and Ecotoxicology (LEAE)Freshwater and OceaniC sciences Unit of reSearch (FOCUS), Chemistry Institute, B ât. B6C, University of Liège, 11 allée du 6 Août, Sart-Tilman, B-4000 Liège, Belgium
}

either agonists or antagonists (Matthiessen and Sumpter 1998). Consequently, invertebrate orthologs of these receptors are potential targets for EDCs, and could be involved in endocrine disruption. However, to date, steroid receptors have not been identified in all invertebrates. For example, although estrogen receptors orthologs have been reported in mollusks (Thornton 2003; Zhang et al. 2012) or annelids (Lv et al. 2017), these receptors are absent in Ecdysozoans. This suggests that other signaling pathways may be impacted by EDCs, such as the retinoic pathway, via the nuclear retinoid X (RXR) and retinoid acid (RAR) receptors (Novák et al. 2009; Santos et al. 2012). RXR are the most widely found in metazoans with high homology between taxa and reportedly targeting multiple signaling pathways. On the contrary, RAR were initially restricted to chordates, but advances in genome sequencing in invertebrates have revealed the presence of RAR in other organisms such as ambulacrarians (sea urchins) and 
lophotrochozoans (annelids and molluscs) (HandbergThorsager et al. 2018; André et al. 2019). While RXR act either as homodimer or heterodimer with other nuclear receptors (e.g. peroxisome proliferator-activated receptors), RAR are mainly active in form of RAR/RXR heterodimers, where RXR is a silent partner that requires no ligand (Germain et al. 2003).

RXR and RAR are mainly activated by small lipophilic ligands (e.g. 9-cis retinoic acid, all-trans retinoid acidDawson and Xia 2012); therefore, many studies have focused on EDCs effects on retinoid pathways, for example in vertebrates (e.g. chordates) (Novák et al. 2008). The effects of EDCs on the retinoid signaling pathway in invertebrates have received less attention, mainly due to the lack of knowledge about the endocrine system regulation, although previous investigations have highlighted the retinoid pathway involvement, for example, in the reproduction regulation of crustaceans (Cui et al. 2013; Venkaiah et al. 2019), accentuating their potential involvement in endocrine deregulation. So far, the best known EDC effect on invertebrates is the imposex phenomenon (i.e. masculinization of female gastropods) observed in almost 150 gastropod species exposed to tributyltin (TBT) (Titley-O'Neal et al. 2011), and which has been linked, in many studies, to inappropriate modulations of RXR (Abidli et al. 2013; Nishikawa et al. 2004; Lima et al. 2011; Stange et al. 2012).

Among invertebrates, rotifers often dominate zooplankton populations, especially monogonont species (Ooms-Wilms et al. 1999; Viroux 1999). Monogononts are cyclical parthenogenic species, that go through episodic sexual reproduction in the presence of diverse environmental cues (Gilbert 2003). Consequently, the monogononts reproduction, especially $\mathrm{Bra}$ chionus sp., has been used in ecotoxicology to evaluate the EDC effects caused by xenobiotic exposures, and it was shown that the sexual reproduction is more sensitive to certain chemicals than asexual reproduction (Snell and Carmona 1995; Xi and Feng 2004). Moreover, previous investigations shown that some chemicals known to be EDCs to vertebrates, such as flutamide, fenitrothion and cyproterone acetate (i.e. all antiandrogens) impact the sexual reproduction of rotifers at concentration sometimes down to 50 times lower than the No Observed Effect Concentration (NOEC) for asexual reproduction (Preston et al. 2000; Snell and Joaquim-Justo 2007; Gismondi et al. 2019). In fact, Preston et al. (2000) demonstrated that exposures to flutamide (non-steroidal anti-androgen) at 1 and $10 \mu \mathrm{g} \mathrm{L}^{-1}$ decreased the fertilization rate and the resting egg production of Brachionus calyciflorus females. In the same way, Ferrando et al. (1996) highlighted that the organophosphorus pesticide fenitrothion decreased the intrinsic rate of natural increase, generation time, net reproductive rate, and life expectancy of B. calyciflorus; while Lv et al. (2010) observed that fenitrothion caused an increase in the duration of the juvenile period, reproductive period, and lifetime reproduction in the same organism. Recently, Gismondi et al. (2019) underlined an increase of the number of oocytes in B. calyciflorus neonate females which mothers has been exposed to the cyproterone acetate, an anti-androgen and progestogen synthetic steroid.

Although these studies demonstrated that some steroid compounds disturb the sexual reproduction of Brachionus sp., Kim et al. (2017), who investigated nuclear receptors of Brachionus sp., highlighted the absence of steroid receptors (e.g. androgen receptor, progesterone receptor) in four Brachionus species. Only an estrogen receptor was discovered in all studied species, but its role remains unclear if we consider that previous works didn't observe endocrine disruption effects caused by an estradiol exposure in $B$. plicatilis (Gallardo et al. 1997) and B. calyciflorus (Preston et al. 2000). Endocrine disruption studies in B. calyciflorus shows that Brachionus sp. are more sensitive to androgen and anti-androgen compounds than estrogenic ones. However, the absence of an androgen receptor (Kim et al. 2017) suggests the involvement of other nuclear receptors. Consequently, due to the presence of RXR and RAR in $B$. calyciflorus (Kim et al. 2017), the present work was devoted to studying the effects of flutamide, fenitrothion and cyproterone acetate, three anti-androgenic compounds that disrupt the sexual reproduction of B. calyciflorus (Ferrando et al. 1996; Preston et al. 2000; Gismondi et al. 2019), on the relative mRNA levels of RXR and RAR, to assess whether the retinoid signaling pathway could be a good starting point in understanding the molecular mechanisms involved in the endocrine disruption of rotifers.

\section{Material and methods}

\section{Experimental animals}

The B. calyciflorus (Pallas) strain used in tests comes from batch production of cysts at the Georgia Institute of Technology (GA, USA) of a strain originally collected in temporary pounds in 1983 by Snell in Gainesville (FL) (Snell et al. 1991). Since then, it has been cultured continuously with periodic collection and storage of resting eggs (cysts). Therefore, initial test animals were obtained by hatching cysts at $25^{\circ} \mathrm{C}$ under continuous illumination.

\section{Exposure conditions, RNA extraction and CDNA synthesis}

The study was carried out using 3 concentrations of each chemical: fenitrothion $\left(0.01,0.1,1 \mathrm{mg} \mathrm{L}^{-1}\right)$, flutamide $\left(0.01,0.1,1 \mathrm{mg} \mathrm{L}^{-1}\right)$ and cyproterone acetate $(\mathrm{CPA}-0.02$, $0.2,2 \mathrm{~m} \mathrm{~L}^{-1}$ ), chosen according to results of preliminary tests so that the highest concentration tested was close to the 
Table 1 Specific primers used to evaluate and normalized the variation of mRNA levels of RXR and RAR by realtime PCR

\begin{tabular}{lllll}
\hline Genes & Primers & Efficiency & Primers final concentration & Sequences $\left(5^{\prime}-3^{\prime}\right)$ \\
\hline RXR & RXR-F & $97.0 \%$ & $150 \mathrm{nM}$ & CTG CAG CTG CCG CTA TAA ATG \\
& RXR-R & & & ACC CTC ACA ACT ATG CAC ACC \\
RAR & RAR-F & $98.4 \%$ & $150 \mathrm{nM}$ & CAA ACA ACA AGC TCT TCA CTG CC \\
& RAR-R & & & GCT TCT TTT GAC ATT CCA ACA GCG \\
EF1 $\alpha$ & EF1 $\alpha-F$ & $99.2 \%$ & $150 \mathrm{nM}$ & AGC CGA AAG AGA ACG TGG TAT \\
& EF1 $\alpha-\mathrm{R}$ & & & CGG CTT GTG ATG TAC CAG TG \\
\hline
\end{tabular}

no observed effect concentration (NOEC) for asexual reproduction (data not shown). Test solutions were firstly prepared in acetone and then diluted in Volvic ${ }^{\oplus}$ mineral water (final acetone concentration: $0.02 \% \mathrm{v}-\mathrm{v}$ ); therefore, a solvent control, called thereafter "acetone" (0.02\% v-v), was also performed. Although a preliminary investigation showed that acetone $0.02 \% \mathrm{v}-\mathrm{v}$ doesn't impact the asexual reproduction of $B$. calyciflorus (data not shown), a control condition (Volvic mineral water only) was performed to ensure the absence of acetone effect on both gene expressions. No significant differences were observed between control and acetone conditions (Anova test, p-value $>0.05$ ); consequently, thereafter, relative mRNA levels measured in exposure conditions were only compared to acetone control.

In order to evaluate the effects of EDCs at the molecular level, the experiments were carried out under the same conditions as previous studies demonstrating effects on the reproduction of B. calyciflorus. Briefly, exposures were carried out in $16 \times 150 \mathrm{~mm}$ glass test tubes containing $12 \mathrm{~mL}$ of exposure media. Two hundred neonate $B$. calyciflorus females aged of $4 \mathrm{~h}$ were placed in each test tube and incubated in the dark at $25^{\circ} \mathrm{C}$ for 6, 12 and $24 \mathrm{~h}$. Rotifers were not fed during the exposure to avoid chemical adsorptions on food. Three replicates were run for each concentration of tested chemicals and acetone.

At the end of each time of exposure, total RNA of rotifers was extracted using the Nucleospin RNA XS kit (MachereyNagel, Germany) following the manufacturer's instructions which included an on-column DNA digestion. The RNA integrity was checked on a $1.5 \%$ agarose gel electrophoresis in TAE buffer (Tris $40 \mathrm{mM}$, acetic acid $1 \mathrm{mM}$, EDTA $40 \mathrm{mM}$ ). Then, RNA concentrations were measured using a NanoDrop ND-1000 spectrometer (NanoDrop, USA), and all ratios A260/ 280 were between 1.9 and 2. Reverse transcriptions were performed on $150 \mathrm{ng}$ total RNA, using the RevertAid First Strand cDNA Synthesis Kit (Thermo Scientific) with random hexamers, and following the manufacturer's protocol.

\section{qPCR analysis}

RXR and RAR primers were designed according to the sequence available on GenBank database (respective accession numbers: MF360875, MF360874-Kim et al. 2017) (Table 1), and the optimal concentration of primers was evaluated across three final concentrations (i.e., 150, 300, and $600 \mathrm{nM}$ ). Dilutions of a cDNA mixture (i.e., a mixture of $1 \mu \mathrm{l}$ of each sample) between 1:2 and 1:128 were also tested to estimate the polymerase chain reaction (PCR) efficiency of primers (Table 1). Two no template controls per primer pair were performed as the negative control to assess external contamination resulting in a non-specific increase of the fluorescence signal.

PCR analyses were carried out on a final volume of $10 \mu \mathrm{L}$ containing $2 \mu \mathrm{L}$ of diluted cDNA, $5 \mu \mathrm{L}$ of iTaq $^{\mathrm{TM}}$ Universal $\mathrm{SYBR}^{\circledR}$ Green Supermix (BioRad, Temse, Belgium), $1 \mu \mathrm{L}$ of primer mix and $2 \mu \mathrm{L}$ of water. PCR program consisted of 15 min initial denaturation at $95^{\circ} \mathrm{C}$ followed by 44 cycles of denaturation at $95^{\circ} \mathrm{C}$ for $15 \mathrm{~s}$, annealing/polymerization at $59^{\circ} \mathrm{C}$ for $45 \mathrm{~s}$. After amplification, a melting curve of PCR products $\left(65-95^{\circ} \mathrm{C}\right.$ with $0.5^{\circ} \mathrm{C}$ increments at $\left.5 \mathrm{~s} / \mathrm{step}\right)$ was performed to ensure the absence of artefacts amplification. The relative transcript levels of RXR and RAR were calculated using the $2^{-\Delta \Delta \mathrm{Ct}}$ method (Livak and Schmittgen 2001) considering the PCR efficiency. Results were normalized using elongation factor 1-alpha $(\mathrm{EF} 1 \alpha)$ as housekeeping gene and acetone group, as control group.

\section{Statistical analysis}

Statistical analyses were carried out with the Addinsoft (2019). The data met normality and variance homogeneity which were tested with the Shapiro-Wilk and the Bartlett tests, respectively. In order to test the influence of exposure conditions, ANOVA test was performed on data obtained at each duration of exposure, followed by Tukey's HSD post hoc tests, to describe significant differences as compared to respective acetone control. A probability value of less than 0.05 was regarded as significant.

\section{Results}

\section{Variations of RXR mRNA level}

RXR mRNA level was measured in B. calyciflorus exposed at three concentrations of three anti-androgen compounds during 6, 12 and $24 \mathrm{~h}$. Results obtained after each duration 

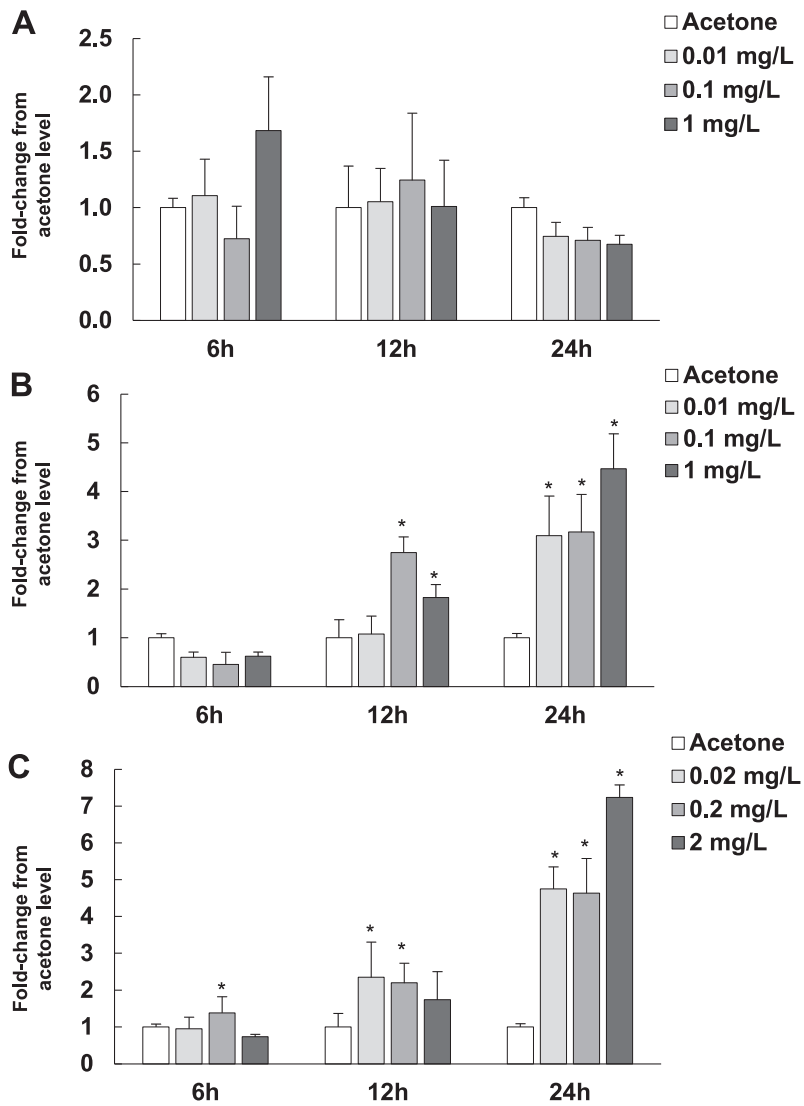

Fig. 1 Relative mRNA levels of RXR in B. calyciflorus exposed to fenitrothion $0.01,0.1$, and $1 \mathrm{mg} \mathrm{L}^{-1}$ (A), flutamide $0.01,0.1$, and $1 \mathrm{mg} \mathrm{L}^{-1}(\mathbf{B})$, and cyproterone acetate $0.02,0.2,2 \mathrm{mg} \mathrm{L}^{-1}$ (C) for 6 , 12 , and $24 \mathrm{~h}$. In parallel, a negative control (i.e., acetone) was performed. Histogram bars represent means \pm standard deviation $(n=3)$. For each duration of exposure, asterisks indicate significant differences as compared to respective acetone control $(P<0.05)$

of exposure to fenitrothion did not show significant difference in RXR mRNA levels, whatever the fenitrothion concentration and the duration of exposure (Fig. 1A).

In B. calyciflorus exposed to flutamide, relative mRNA level of RXR was influenced by the concentration and the time of exposure (ANOVA, $p$-value $<0.05$; Fig. 1B). RXR mRNA level was unchanged after $6 \mathrm{~h}$ of exposure, regardless the concentration of exposure. At $12 \mathrm{~h}$ of exposure, no change was measured at the lower flutamide concentration (i.e. $0.01 \mathrm{mg} \mathrm{L}^{-1}$ ), while RXR mRNA level was 2.7 - and 1.8-fold increased at 0.1 and $1 \mathrm{mg} \mathrm{L}^{-1}$, respectively, as compared to respective control (Fig. 1B). Finally, a $24 \mathrm{~h}$ exposure caused an increase of the relative mRNA level of RXR from 3 to 4.5fold as compared to the control group, whatever the exposure concentration.

After exposure to cyproterone acetate, RXR mRNA level was also modified in B. calyciflorus, according to the concentration and the time of exposure (Fig. 1C). After $6 \mathrm{~h}$ of exposure, an increase of RXR mRNA level was only measured at $0.2 \mathrm{~m} \mathrm{~L}^{-1}$, as compared to respective control;
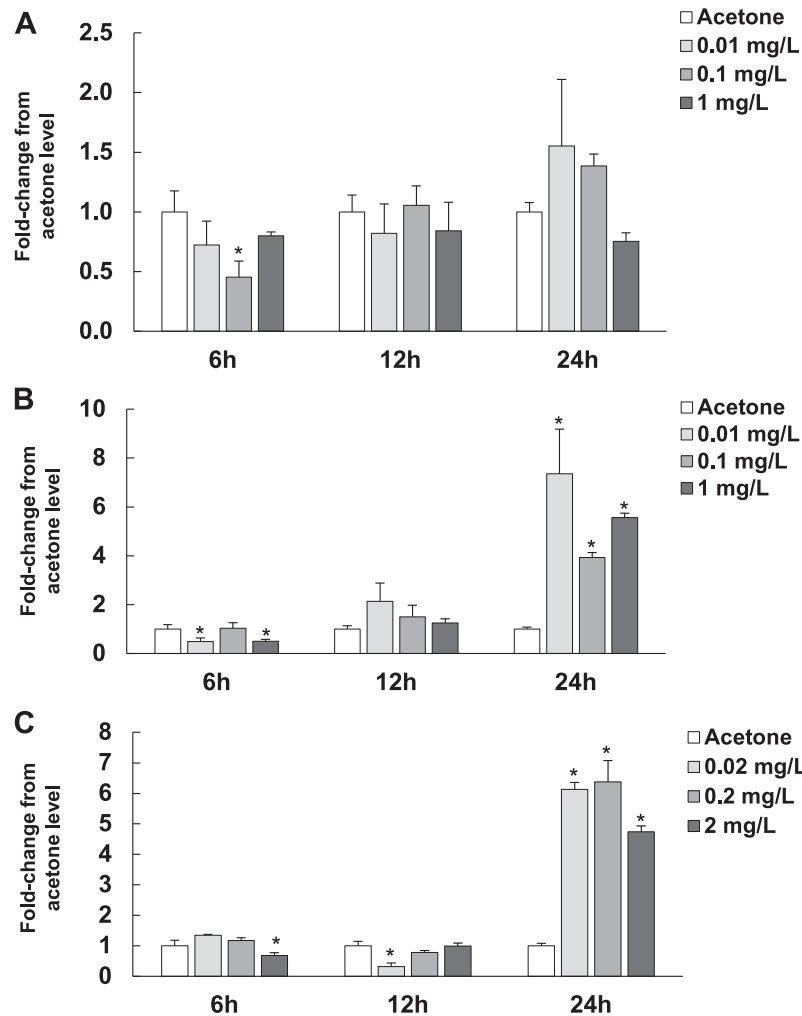

Fig. 2 Relative mRNA levels of RAR in B. calyciflorus exposed to fenitrothion $0.01,0.1$, and $1 \mathrm{mg} \mathrm{L}^{-1}(\mathbf{A})$, flutamide $0.01,0.1$, and $1 \mathrm{mg}$ $\mathrm{L}^{-1}(\mathbf{B})$, and cyproterone acetate $0.02,0.2,2 \mathrm{mg} \mathrm{L}^{-1}(\mathbf{C})$ for 6,12 , and $24 \mathrm{~h}$. In parallel, a negative control (i.e., acetone) was performed. Histogram bars represent means \pm standard deviation $(n=3)$. For each duration of exposure, asterisks indicate significant differences as compared to respective acetone control $(P<0.05)$

whereas after $12 \mathrm{~h}$ of exposure, 0.02 and $0.2 \mathrm{mg} \mathrm{L}^{-1}$ both induced a 2.2-fold increase of relative mRNA level of RXR. Finally, the $24 \mathrm{~h}$ exposure to CPA resulted to the increase of RXR mRNA levels from 5 to 7-times, as compared to respective control, regardless the concentration of exposure.

\section{Variations of RAR mRNA level}

As RXR gene, RAR mRNA level was measured in $B$. calyciflorus after 6,12 and $24 \mathrm{~h}$ of exposure at three concentrations of fenitrothion, flutamide and cyproterone acetate.

Relative mRNA level of RAR was not significantly changed after fenitrothion exposure, except after $6 \mathrm{~h}$ of exposure to fenitrothion $0.1 \mathrm{mg} \mathrm{L}^{-1}$ where it was twice decreased (Fig. 2A).

In $B$. calyciflorus exposed to flutamide, RAR mRNA level was influenced by flutamide concentration and time of exposure (Fig. 2B). After $6 \mathrm{~h}$ of exposure, relative mRNA level of RAR was halved at 0.01 and $1 \mathrm{mg} \mathrm{L}^{-1}$ of flutamide, but no change was observed at $0.1 \mathrm{mg} \mathrm{L}^{-1}$. Besides, although no significant differences were observed after $12 \mathrm{~h}$ 
of exposure, relative mRNA level of RAR was significantly 7.3-, 3.9- and 5.6-fold increased after a 24-h exposure to $0.01,0.1$ and $1 \mathrm{mg} \mathrm{L}^{-1}$ flutamide, respectively.

After exposure to cyproterone acetate, RAR mRNA level was also modified in $B$. calyciflorus, according to the concentration and the time of exposure (Fig. 2C). Results revealed that relative mRNA level of RAR was 1.5-fold lower after $6 \mathrm{~h}$ of exposure to CPA $2 \mathrm{mg} \mathrm{L}^{-1}$ and has been 3 times less expressed after $12 \mathrm{~h}$ of exposure to CPA $0.02 \mathrm{mg} \mathrm{L}^{-1}$, as compared to respective acetone group. Finally, after $24 \mathrm{~h}$ of exposure, RAR mRNA level was from 4.7 to 6.4 times significantly increased, regardless the CPA concentration.

\section{Discussion}

One of the major challenges in assessing the toxicity of endocrine disrupting compounds is the understanding of their mechanisms of action. Therefore, this present work aimed at investigating the in the relative mRNA levels of the retinoid $\mathrm{X}$ receptor (RXR) and retinoid acid receptor (RAR) in Brachionus calyciflorus exposed to flutamide, fenitrothion and cyproterone acetate, three anti-androgen compounds known to disrupt the sexual reproduction of rotifers (Preston et al. 2000; Snell and Joaquim-Justo 2007; Gismondi et al. 2019). Among the compounds tested in this study, fenitrothion was the only one that did not induce significant change the relative mRNA levels of RXR and RAR. Ferrando et al. (1996) and Lv et al. (2010) highlighted fenitrothion effects on $B$. calyciflorus reproduction such as a decrease of the intrinsic rate of natural increase, the net reproductive rate, and the lifetime reproduction. These disturbances could be the consequence of indirect or direct effects of fenitrothion on the endocrine system of B. calyciflorus. Our results showed no effect of fenitrothion on RXR and RAR mRNA levels suggesting that retinoid signaling pathways seem not involved in the EDC effects caused by fenitrothion. Several hypotheses could explain these results, starting with the fact that the effects of fenitrothion on $B$. calyciflorus reproduction observed in Ferrando et al. (1996) and Lv et al. (2010) were measured after several days of exposure, while our study focused on studying changes in the RXR and RAR mRNA levels, from the first $24 \mathrm{~h}$ of exposure. Consequently, we can assume that, if endocrine disruption effects of fenitrothion are directly mediated through retinoid pathways, they could occur after $24 \mathrm{~h}$ of exposure of B. calyciflorus. EDC effects observed after fenitrothion exposure could also be the consequence of the interaction with other receptors, because fenitrothion is known to be an androgenic receptor antagonist, however no androgenic receptor was discovered in four different Brachionus species (Kim et al. 2017). From another point of view, the main fenitrothion effects observed in previous studies were measured on the sexual reproduction of
B. calyciflorus. However, our results were obtained on asexual females, since the hatching of resting eggs produce only asexual females (Gilbert 2003) and that no males or cysts, both proven a sexual reproduction, were identified at the end of each duration of exposure (i.e. 6, 12 and $24 \mathrm{~h}$ ). It could thus be assumed that the disruption of the sexual reproduction observed after exposure to fenitrothion could be caused by fenitrothion effects on males rather than females, for example on spermatogenesis or sperm quality, as it has already been observed in rats (Taib et al. 2013). Finally, it cannot be ignored that fenitrothion is known to be a cholinesterase inhibitor and that it has been observed in rats that inhibition of cholinesterase can reduce serum levels of growth hormone and thyroid hormone (Smallridge et al. 1991). However, the limited knowledge of the endocrine system of rotifers (e.g., no known hormones) does not yet allow this hypothesis to be tested.

Flutamide and cyproterone acetate caused changes in the relative levels of RXR and RAR mRNA after the first $12 \mathrm{~h}$ of exposure (i.e. a decrease in the RAR mRNA level and an increase in the RXR mRNA level), suggesting that the two pollutants affect the two receptors differently during the first few hours of exposure. These results could be the consequence of the impact of flutamide and cyproterone acetate on the metabolism of ligands, which could be different for both receptors (Allenby et al. 1993). In fact, Kamei et al. (1993) observed in mouse that RAR mRNA expression was rapidly (within $2 \mathrm{~h}$ ) induced by exposure to its ligand, the all-trans retinoid acid. Similarly, Mangelsdorf et al. (1992) highlighted in rats and mouse that 9-cis retinoic acid (ligand of RXR) exposure induced an increase of mRNA levels of RXR. For example, it can be hypothesized that the decrease in RAR mRNA level could result from a decrease in all-trans retinoic acid content, which would be consistent with the results of Zhou et al. (2019) who measured a decrease in alltrans RNA concentration in rats exposed to flutamide. Similarly, increases in RXR mRNA levels, especially observed at $12 \mathrm{~h}$ of exposure, could be related to the increase in 9-cis retinoic acid concentration. Conversely, both flutamide and cyproterone acetate caused a significant increase in both RXR and RAR mRNA levels after $24 \mathrm{~h}$ of exposure. Preston et al. (2000) shown decrease of the fertilization rate of $B$. calyciflorus exposed to 1 and $10 \mu \mathrm{g} \mathrm{L}^{-1}$ of flutamide. Besides, although higher flutamide concentrations were not tested in Brachionus sp., Haeba et al. (2008) observed a delay in the maturity of Daphnia magna (and thus an increase in the time to first reproduction) when exposed to $1 \mathrm{mg} \mathrm{L}^{-1}$ of flutamide, explaining this result by a potential interaction of flutamide with steroid receptor analogs in Daphnia. In the same way, oocysts and resting eggs productions were increased in B. calyciflorus exposed to CPA, and a cross-mating experiment confirmed that CPA effects on $B$. calyciflorus reproduction were caused through females 
rather than males (Gismondi et al. 2019). Knowing that $B$. calyciflorus and Daphnia sp. have no androgen receptor (Thomson et al. 2009; Litoff et al. 2014; Kim et al. 2017), it could be assumed that the effects of flutamide and cyproterone acetate on organism reproduction could be mediated through another signaling pathways which could potentially be the retinoid signaling pathway, considering the present results. This assumption is corroborated by the fact that concomitant significant increase the relative mRNA levels of RXR and RAR, known to act as heterodimers (Germain et al. 2003), have been observed after $24 \mathrm{~h}$ of exposure to flutamide or cyproterone acetate. Moreover, Bettin et al. (1996) shown in gastropods that cyproterone acetate was able to inhibit imposex induction by TBT, known to act through RXR pathways (Abidli et al. 2013; Lee et al. 2019; Nishikawa et al. 2004; Lima et al. 2011; Stange et al. 2012). Similar profiles of expression after $24 \mathrm{~h}$ of exposure could result from a change in the metabolism of the 9-cis-retinoid acid which can bind to both RAR and RXR. However, further studied are necessary to confirm this assumption.

Finally, it cannot be ignored that other endocrine pathways may be involved in the endocrine disruption effects caused by anti-androgenic compounds. For example, cyproterone acetate has also been shown to have low progestin activity (Poyet and Labrie 1985). Therefore, the effects of CPA could be related to the presence of a membrane-associated progesterone receptor (MAPR), which has been reported in B. manjavacas and B. plicatilis (Stout et al. 2010; Smith et al. 2011). However, to date, there is no evidence of MAPR in B. calyciflorus.

Consequently, further research is needed to better understand the endocrine system and endocrine disruption of rotifers. For example, future approaches could involve evaluating the potential binding between anti-androgenic compounds (i.e. flutamide and cyproterone acetate) and the two retinoid receptors to assess the activation or inhibition of signaling pathways. It would also be interesting to determine the presence of MAPR and to study its involvement in the endocrine system and its disruption. Finally, transcriptomics (i.e. RNA-seq) could provide more information and knowledge about the signaling pathways potentially involved in the endocrine disruption caused by these anti-androgens, but the limited knowledge of the endocrine system of $B$. calyciflorus could prevent this.

\section{Conclusion}

The present work was devoted to studying the modulation of RXR and RAR mRNA levels in the monogonont $B$. calyciflorus exposed to fenitrothion, flutamide and cyproterone acetate, three anti-androgens known to disrupt the sexual reproduction of rotifers. The results showed that, with the exception of the fenitrothion pesticide, flutamide and cyproterone acetate increased the relative mRNA levels of both RXR and RAR genes, in the first $24 \mathrm{~h}$ of exposure. In addition, CPA appeared to have a higher impact on RXR and RAR mRNA levels than flutamide, probably due to its progestational activity and the presumed presence of a membrane-associated progesterone receptor, as reported in B. manjavacas and B. plicatilis.

To conclude, although it is still difficult to confirm the involvement of the retinoid pathway in the endocrine disruption in Brachionus sp., and that further investigations are necessary to study and prove the interaction between EDC compounds and the retinoid receptors, results of this work suggest that the retinoid signaling pathway seems to be a good starting point for trying to understand the mechanisms of action related to the dysfunction of sexual reproduction of Brachionidae.

\section{Compliance with ethical standards}

Conflict of interest The authors declare that they have no conflict of interest.

Ethical approval This article does not contain any studies with animals performed by any of the authors.

Informed consent All authors are willing to submit the paper.

Publisher's note Springer Nature remains neutral with regard to jurisdictional claims in published maps and institutional affiliations.

\section{References}

Abidli S, Castro LFC, Lahbib Y, Reis-Henriques MA, El Menif NT, Santos MM (2013) Imposex development in Hexaplex trunculus (Gastropoda: Caenogastropoda) involves changes in the transcription levels of the retinoid X receptor (RXR). Chemosphere 93(6):1161-1167

Addinsoft (2019) XLSTAT 2019: data analysis and statistical solution for Microsoft Excel. Paris, France

Allenby G, Bocquel MT, Saunders M, Kazmer S, Speck J, Rosenberger M, Lovey A, Kastner P, Grippo JF, Chambon P (1993) Retinoic acid receptors and retinoid $\mathrm{X}$ receptors: interactions with endogenous retinoic acids. Proc Natl Acad Sci 90(1):30-34

André A, Ruivo R, Fonseca E, Froufe E, Castro LFC, Santos MM (2019) The retinoic acid receptor (RAR) in molluscs: function, evolution and endocrine disruption insights. Aquat Toxicol 208:80-89

Bettin C, Oehlmann J, Stroben E (1996) TBT-induced imposex in marine neogastropods is mediated by an increasing androgen level. Helgoländer Meeresun 50(3):299-317

Cui J, Wu L, Chan SM, Chu KH (2013) cDNA cloning and mRNA expression of retinoid-X-receptor in the ovary of the shrimp Metapenaeus ensis. Mol Biol Rep 40(11):6233-6244

Dawson MI, Xia Z (2012) The retinoid X receptors and their ligands. BBA-Mol Cell Biol L 1821(1):21-56

Ferrando MD, Sancho E, Andreu-Moliner E (1996) Chronic toxicity of fenitrothion to an algae (Nannochloris oculata), a rotifer 
(Brachionus calyciflorus), and the cladoceran (Daphnia magna). Ecotox Environ Safe 35(2):112-120

Gallardo WG, Hagiwara A, Tomita Y, Soyano K, Snell TW (1997) Effect of some vertebrate and invertebrate hormones on the population growth, mictic female production, and body size of the marine rotifer Brachionus plicatilis Müller. Hydrobiologia 358(1-3):113-120

Germain P, Altucci L, Bourguet W, Rochette-Egly C, Gronemeyer H (2003) Nuclear receptor superfamily: principles of signaling Pureand Applied Chemistry 75(11-12):1619-1664

Gilbert JJ (2003) Environmental and endogenous control of sexuality in a rotifer life cycle: developmental and population biology. Evol Dev 5(1):19-24

Gismondi E, Cauchie HM, Cruciani V, Joaquim-Justo C (2019) Targeted impact of cyproterone acetate on the sexual reproduction of female rotifers. Ecotoxicology 28(6), 643-649

Haeba MH, Hilscherová K, Mazurová E, Bláha L (2008) Selected endocrine disrupting compounds (vinclozolin, flutamide, ketoconazole and dicofol): effects on survival, occurrence of males, growth, molting and reproduction of Daphnia magna. Environ Sci Pollut R 15(3):222

Handberg-Thorsager M, Gutierrez-Mazariegos J, Arold ST, Nadendla EK, Bertucci PY, Germain P, Tomançak P, Pierzchalski K, Jones JW, Albalat R, Kane MA, Bourguet W, Laudet V, Arendt D, Schubert M (2018) The ancestral retinoic acid receptor was a lowaffinity sensor triggering neuronal differentiation. Science Adv 4 (2):eaao1261

Kamei Y, Kawada T, Kazuki R, Sugimoto E (1993) Retinoic acid receptor $\gamma 2$ gene expression is up-regulated by retinoic acid in 3T3-L1 preadipocytes. Biochem J 293(3):807-812

Kim DH, Kim HS, Hwang DS, Kim HJ, Hagiwara A, Lee JS, Jeong CB (2017) Genome-wide identification of nuclear receptor (NR) genes and the evolutionary significance of the NR1O subfamily in the monogonont rotifer Brachionus spp. Gen Comp Endocr 252:219-225

Lee MC, Fonseca E, Park JC, Yoon DS, Choi H, Kim M, Han J, Cho HC, Shin KH, Santos ML, Jung JH, Castro LFC, Lee JS (2019) Tributyltin affects retinoid X receptor-mediated lipid metabolism in the marine rotifer Brachionus koreanus. Environ Sci Technol 53(13): 7830-7839

Lima D, Reis-Henriques MA, Silva R, Santos AI, Castro LFC, Santos MM (2011) Tributyltin-induced imposex in marine gastropods involves tissue-specific modulation of the retinoid $\mathrm{X}$ receptor. Aquat Toxicol 101(1):221-227

Litoff EJ, Garriott TE, Ginjupalli GK, Butler L, Gay C, Scott K, Baldwin WS (2014) Annotation of the Daphnia magna nuclear receptors: comparison to Daphnia pulex. Gene 552(1):116-125

Livak KJ, Schmittgen TD (2001) Analysis of relative gene expression data using real-time quantitative PCR and the $2^{-\Delta \Delta C T}$ method. Methods 25(4):402-408

Lv L, Snell TW, Yang J, Li S, Zhu W (2010) Effects of fenitrothion on life history parameters of the rotifer Brachionus calyciflorus. J Freshwater Ecol 25(4):589-598

Lv L, Dong X, Lv F, Zhao W, Yu Y, Yang W (2017) Molecular cloning and characterization of an estrogen receptor gene in the marine polychaete Perinereis aibuhitensis. Comp Biochem Phys B 207:15-21

Mangelsdorf DJ, Borgmeyer U, Heyman RA, Zhou JY, Ong ES, Oro AE, Kakizuka A, Evans RM (1992) Characterization of three RXR genes that mediate the action of 9-cis retinoic acid. Genes Dev 6(3):329-344

Matthiessen P (2003) Endocrine disruption in marine fish. Pure Appl Chem 75(11-12):2249-2261

Matthiessen P, Sumpter JP (1998) Effects of estrogenic substances in the aquatic environment. In: Fish ecotoxicology. Birkhäuser, Basel, p 319-335
Nishikawa JI, Mamiya S, Kanayama T, Nishikawa T, Shiraishi F, Horiguchi $T$ (2004) Involvement of the retinoid $X$ receptor in the development of imposex caused by organotins in gastropods. Environ Sci Tech 38(23):6271-6276

Novák J, Beníšek M, Hilscherová K (2008) Disruption of retinoid transport, metabolism and signaling by environmental pollutants. Environ Int 34(6):898-913

Novák J, Jálová V, Giesy JP, Hilscherová K (2009) Pollutants in particulate and gaseous fractions of ambient air interfere with multiple signaling pathways in vitro. Environ Int 35:43-49

Ooms-Wilms AL, Postema G, Gulati RD (1999) Population dynamics of planktonic rotifers in Lake Loosdrecht, the Netherlands, in relation to their potential food and predators. Freshwater Biol 42 (1):77-97

Poyet P, Labrie F (1985) Comparison of the antiandrogenic/androgenic activities of flutamide, cyproterone acetate and megestrol acetate. Mol Cell Endocrinol 42(3):283-288

Preston BL, Snell TW, Robertson TL, Dingmann BJ (2000) Use of freshwater rotifer Brachionus calyciflorus in screening assay for potential endocrine disruptors. Environ Toxicol Chem 19 (12):2923-2928

Santos MM, Reis-Henriques MA, Castro LFC (2012) Lipid homeostasis perturbation by organotins: effects on vertebrates and invertebrates in biochemical and biological effects of organotins. In: Pagliarani A, Trombetti F, Ventrella V (eds) Biochemical and biological effects of organotins. Bentham Science, Italy, p 83-96

Smallridge RC, Carr FE, Fein HG (1991) Diisopropylfluorophosphate (DFP) reduces serum prolactin, thyrotropin, luteinizing hormone, and growth hormone and increases adrenocorticotropin and corticosterone in rats: involvement of dopaminergic and somatostatinergic as well as cholinergic pathways. Toxicol Applied Pharm 108(2):284-295

Smith HA, Welch DBM, Snell TW (2011) Molecular evolution of the membrane associated progesterone receptor in the Brachionus plicatilis (Rotifera, Monogononta) species complex. Hydrobiologia 662(1):99-106

Snell TW, Moffat BD, Janssen C, Persoone G (1991) Acute toxicity tests using rotifers: IV. Effects of cyst age, temperature, and salinity on the sensitivity of Brachionus calyciflorus. Ecotox Environ Saf 21(3):308-317

Snell TW, Carmona MJ (1995) Comparative toxicant sensitivity of sexual and asexual reproduction in the rotifer Brachionus calyciflorus. Environ Toxicol Chem 14(3):415-420

Snell TW, Joaquim-Justo C (2007) Workshop on rotifers in ecotoxicology. Hydrobiologia 593(1):227-232

Stange D, Sieratowicz A, Oehlmann J (2012) Imposex development in Nucella lapillus-evidence for the involvement of retinoid $\mathrm{X}$ receptor and androgen signalling pathways in vivo. Aquat Toxicol 106:20-24

Stout EP, La Clair JJ, Snell TW, Shearer TL, Kubanek J (2010) Conservation of progesterone hormone function in invertebrate reproduction. Proc Natl Acad Sci U S A 107(26):11859-11864

Taib IS, Budin SB, Ghazali AR, Jayusman PA, Louis SR, Mohamed J (2013) Fenitrothion induced oxidative stress and morphological alterations of sperm and testes in male sprague-dawley rats. Clinics 68(1):93-100

Thomson SA, Baldwin WA, Wang YH, Kwon G, LeBlanc GA (2009) Annotation, phylogenetics, and expression of the nuclear receptors in Daphnia pulex. BMC Genom 10(1):500

Thornton JW (2003) Resurrecting the ancestral steroid receptor: ancient origin of estrogen signaling. Science 301:1714-1717

Titley-O'Neal CP, Munkittrick KR, MacDonald BA (2011) The effects of organotin on female gastropods. J Environ Monit 13 (9):2360-2388 
Venkaiah K, Thathapudi D, Sainath SB (2019) Detection and mode of action of retinoids on ovarian development in the mud crab, Scylla serrata. Int J Aquat Biol 7(5):245-253

Viroux L (1999) Zooplankton distribution in flowing waters and its implications for sampling: case studies in the River Meuse (Belgium) and the River Moselle (France, Luxembourg). J Plankton Res 21(7):1231-1248

World Health Organization (WHO) (2002) Global assessment of the state-of-the-science of endocrine disruptors. International Program on Chemical Safety, Geneva, Switzerland, p 180

Xi YL, Feng LK (2004) Effects of thiophanate-methyl and glyphosate on asexual and sexual reproduction in the rotifer
Brachionus calyciflorus Pallas. Bull Environ Contam Toxicol 73(4):644-651

Zhang H, Pan L, Zhang L (2012) Molecular cloning and characterization of estrogen receptor gene in the Scallop Chlamys farreri: expression profiles in response to endocrine disrupting chemicals. Comp Biochem Phys C 156:51-57

Zhou Y, Zhang D, Hu D, Liu B, Peng J, Shen L, Chunlan L, Yihang $\mathrm{H}$, Yuanyuan $\mathrm{Z}$, Xing L, Xu T, Peter T, Tao L, Dawei H, Guanghui W (2019) Retinoic acid: a potential therapeutic agent for cryptorchidism infertility based on investigation of flutamideinduced cryptorchid rats in vivo and in vitro. Reprod Toxicol 87:108-117 